\title{
Identity Crisis in U.S. Foreign Policy: Discourses of Greatness and Exceptionalism after 2008
}

\author{
Áron Tábor ${ }^{1}$
}

\begin{abstract}
By the end of the first decade of the twenty-first century, the United States had to face a number of interrelated crises: the economic and financial crisis of 2008-09 coincided with the military overexpansion resulting from interventions in Afghanistan and Iraq. These developments culminated in a crisis of foreign-policy identity: the notion refers to a situation in which well-established conceptions of a country's role in the international system are questioned, and new conceptions are created and reproduced. For the U.S., this manifested in a challenge to the unipolar leadership role that had been widely accepted in the post-Cold War era. Surprisingly, this did not lead to the disappearance of discourses of "American exceptionalism" and "greatness." On the contrary, these ideas gained even greater significance in the foreign-policy debates of the 2010s, although their precise meaning was the subject of intense contestation. What explains this resurgence of exceptionalist rhetoric, and how can we characterize the different themes that appeared in these debates? The article introduces a new theoretical framework for understanding discourses of U.S. exceptionalism, and briefly examines the discourses of the Obama and the Trump presidencies. This analysis can highlight how the use of certain terms may accompany decisive changes in U.S. foreign policy, and how especially the presidency of Donald Trump signals a shift in the understanding of U.S. national role conception.
\end{abstract}

Keywords: U.S. foreign policy, exceptionalism, discourse analysis, role theory

\section{Introduction}

Discourses of national greatness are enduring components of the ideology of U.S. foreign policy (see e.g. Hunt, 1987: 19-45; 127-170), while the notion of "American

\footnotetext{
1 Áron Tábor holds a PhD (2020) in Political Science from Central European University. His dissertation examines the intellectual history of American exceptionalism from the beginning of the twentieth century.
} 
exceptionalism" has become associated with the "unipolar moment" of the United States in the post-Cold War world (Krauthammer, 1990/91). However, even as the unipolar moment had faded by 2008-09 due to the consequences of military overexpansion and economic downturn, these discourses did not disappear, but, on the contrary, became even more widespread amid a re-emerging debate on the nation's purpose. The resurgence of exceptionalist rhetoric suggests that the discourse is not simply a reflection of U.S. power, while the variations in the terms of the discussions show that exceptionalism cannot be fully understood in the context of a single, unchanged ideology of U.S. foreign policy, either. Instead, this article situates the emergence and re-emergence of such discourses within the conditions of crises of foreign-policy identity, i.e. times when well-established conceptions of the country's role in international politics are questioned, and new role conceptions are created and reproduced.

In the U.S. context, such role conceptions are often contested along the lines of two key questions concerning the country's international conduct: first, whether U.S. values and political institutions hold universal relevance; and second, whether the U.S. should actively propagate these very values and institutional arrangements. In much of the post-Cold War period, a universalist and activist consensus dominated U.S. foreign policy. However, as the crisis of 2008-09 began to unfold, alternative discourses also came to the surface, and the debates about the role of the United States during the presidencies of Barack Obama and Donald Trump can be interpreted within this framework. Although Obama remained committed to universalism, he - especially by the end of his second term - argued for a more restrained international posture. On the other hand, during his political rise, Trump questioned the principles of the old consensus, and articulated a strongly particularistic understanding of world politics.

After a brief summary of existing scholarly approaches to "American exceptionalism," the article - building on notions of national role conceptions and identity crises - introduces a new analytical framework to locate relevant discourses. After that, a preliminary analysis of such discourses under the Obama and the Trump presidencies follows.

\section{What is "American exceptionalism"?}

Over the past decade, a growing literature has been focusing on the origins and meaning of U.S. exceptionalism; still, it remains a contested concept given that the term "packs different ideas under the same label" (Ceaser, 2012: 6). Although scholars originally 
understood it in an objective sense, referring to those factors that made the United States "exempt from the very social-historical dynamics governing all other nations" (Rodgers, 2004: 25), more recently it has emerged as a subjective category related to the belief in U.S. distinctiveness in a wide array of fields - most prominently in foreign policy. In this sense, exceptionalism is a discursive construction, often understood as referring to a set of beliefs that create, construct and (re)produce a particular foreign-policy identity (McCrisken, 2008; Onuf, 2012; Restad, 2015).

Within the subjective approach, a large part of the literature treats exceptionalism as a relatively permanent feature of U.S. foreign policy, discerning its content from the philosophical or religious roots of the founding of the United States, or even from earlier periods.

Two major variants of this argument exist: there can be either a single exceptionalist tradition, continuously influencing U.S. foreign policy behavior, or the discourse can be understood to be driven by competing exceptionalisms, often broken into a dichotomy between "good" (multilateralist, internationalist, exemplarist) and "bad" (motivated by unilateralist and missionary impulses) types (see e.g. Deudney and Meiser, 2009; Koh, 2003; Onuf, 2012). The ongoing contestation between the two forms is sometimes explained by cyclical alternations between "quietist" and "activist" phases of exceptionalism (e.g. Hoffmann, 1968: 190-208; 1978: 6); others claim that the "good" form was replaced by a "bad," more interventionist version at a certain point in history. ${ }^{2}$ However, as Hilde Restad (2015: 56-84) convincingly shows, nineteenth-century continental expansionism can hardly be conceived as an "isolationist" understanding of U.S. foreign policy, while proponents of the cyclical theory themselves cannot agree about the durations of the cycles. Restad rather argues that a single exceptionalist tradition motivates a continuous "unilateralist internationalism" foreign-policy outcome. At the same time, such an approach cannot fully explain the very real shifts and contestations within these larger continuities, which will be highlighted in our case.

Whether it is the single-tradition or the competing versions interpretation of exceptionalism, these approaches stress the permanent presence of this notion in the belief systems connected to U.S. foreign policy. However, David Hughes (2015: 536-537)

\footnotetext{
${ }^{2}$ The idea that U.S. foreign policy alternates between periods of "introversion" and "extroversion" was first outlined in: Klingberg (1952). Those who believe in a shift between the two versions, claim that it occurred near the end of the nineteenth-century, or at the time of the two world wars (cf. Tucker and Hendrickson, 1992; McDougall, 1997).
} 
argues that such narratives of exceptionalism often fall into the problem of "reading history backwards," as they reinforce an ahistorical and timeless interpretation of the American self-view. Hughes rather proposes an understanding that posits exceptionalism as "a discourse produced by the 'impressive increase' in US power" beginning after 1945 (Ibid.: 534). At the same time, focusing only on power does not explain the variations in the use of exceptionalism when the concept did arise; it also leaves unanswered the question of why the exceptionalist discourse has seemingly strengthened in times of crises - e.g., around 2008-09, in a period when, arguably, doubt was cast on the sustainability of U.S. omnipotence. To explain this, we need to better understand the connection between crises and exceptionalist discourses, which is outlined in the next section.

\section{Crisis and Exception: Theoretical and Conceptual Background}

\section{National Role Conceptions and Identity Crises}

The underlying assumption of this analysis is the idea that we cannot entirely separate what actors do from what they say; instead, doing by saying is itself a form of action, hence the discursive manifestations of collective self-understandings cannot be discarded as "mere rhetoric." Of course, this approach requires a broader constructivist framework, in which values, norms, and identity discourses play an important role in the shaping of social reality. In this case, our attention needs to turn to those expressions of selfconceptions that relate the U.S. self-view to the country's presumed position in international politics. In the study of foreign policy, these are called "national role conceptions" that are enacted under certain conditions by the leaders of a country (Holsti, 1970; Brummer and Thies, 2015). For the United States, these role conceptions can be discerned from discussions about the country's unique status in the international order, which are often infused with a normative understanding of U.S. responsibility, reflected in roles such as alliance or regional leader, or - especially in the post-Cold War context - even global leader.

Although these role conceptions can be remarkably stable, this is not necessarily the case when their enabling external or internal circumstances change rapidly. In his analysis of the post-1989 resurgence of geopolitical thought in Europe, Stefano Guzzini (2012: 46-47) defines foreign-policy identity crisis as an "anxiety over a new, a newly questioned or a newly acquired self-understanding or role in world affairs" which arises when "the smooth continuation of [a foreign-policy tradition's] interpretative dispositions 
encounters problems, as taken-for-granted self-understandings and role positions are openly challenged, and eventually undermined." Under these conditions, confusion and contestation may arise over the country's desired international role, which, eventually, can lead to the emergence of new role conceptions and discursive constructions.

The end of the Cold War itself can be characterized as the source of such a crisis of U.S. foreign-policy identity: the collapse of the Soviet Union and the end of bipolarity was conceived as a "crisis of representation" (Campbell, 1992: 195-196). However, by redefining the U.S. role in the context of the so-called "unipolar moment," this crisis was ultimately overcome through the adoption of a broad consensus among U.S. foreign policy elites, which was largely unquestioned until the shock of 2008-09.

\section{An Analytical Framework for the Study of U.S. Foreign-Policy Discourses}

The responses to the crises of 2008-09 highlighted that the broad consensus on U.S. foreign-policy identity can hide subtler differences about the exact way the U.S. was supposed to perform its distinguished role in the international order. The renewal of these debates once again drew attention to two key questions related to the international conduct of the United States. First, do actors believe that U.S. values and political institutions hold universal relevance, or do they rather see those as contained in space and time? Second, do they suggest that the U.S. should be actively involved in international affairs on the basis of these very values and arrangements? Depending on the answers to these questions, these identity-related discourses can be characterized along two dimensions: the first one makes a distinction between universalism and particularism, while the second one locates articulations between the endpoints of activism and withdrawal.

\begin{tabular}{|l|l|l|}
\hline & Universalism & Particularism \\
\hline Activism & $\begin{array}{l}\text { Missionary (Manifest Destiny; } \\
\text { democracy promotion) }\end{array}$ & $\begin{array}{l}\text { Moral superiority (defense of } \\
\text { U.S. values); offensive realism }\end{array}$ \\
\hline Withdrawal & $\begin{array}{l}\text { Exemplarism (U.S. as a role } \\
\text { model) }\end{array}$ & Isolationism; defensive realism \\
\hline
\end{tabular}

Table 1. The applicability of American values abroad and foreign-policy positions.

Here, some qualifications are in order. First, while these dimensions create clear analytical delineations, in reality the distinctions are often blurred, and it is better to 
understand the different positions as scales rather than clear-cut categories. Second, the table does not provide a general explanatory framework for the outcomes of U.S. foreign policy but rather a way to interpret rival role conceptions and identity discourses. Furthermore, as was mentioned previously, a simple interventionism-isolationism dichotomy is unable to map the complexity of the U.S. foreign-policy tradition, but, in combination with the universalism-particularism axis, it can still serve as an analytical tool to categorize discourses. ${ }^{3}$

Based on these two dimensions, we can still distinguish between four major categories (see Table 1).

First, universalism and activism refer to the missionary character of U.S. foreign policy: this is the most familiar face of exceptionalism, closest to what advocates of a single tradition view as the dominant form. The messianic attitude is sometimes justified through religious references (e.g. "Manifest Destiny"), in other cases, this is simply connected to the greatness of U.S. values, justifying interventionist ideas such as democracy promotion. However, the universal validity of such values does not necessarily go hand in hand with interventionism: according to a second view, the U.S. should set an example as a role model, but it should still refrain from interfering with the businesses of other nations. This is often called the exemplarist form of exceptionalism, sometimes connected to the biblical trope of a "city on a hill," advocated by those who favor a more restrained foreign policy. Third, an even more limited position is to say that the U.S. should not get involved in the affairs of others because it has no relevant values and approaches to offer. In the extreme case, it can amount to full isolationism, an almost complete separation from international politics - although, of course, rarely embraced in such pure form. Fourth, a seemingly self-contradictory position is to argue for particularism and activism at the same time: the inherent contradiction is sometimes resolved through the complete rejection of value-laden explanations (some realists argue this way, although this is not a typical position in U.S. foreign-policy discourses), or through the presumption of the moral superiority of U.S. values that need strong defense in a hostile world.

\footnotetext{
${ }^{3}$ In a recent contribution, Nymalm and Plagemann (2019) also suggested a categorization of different exceptionalist foreign-policy discourses. Through the analysis of Chinese, Indian, Turkish and U.S. discourses, their two-dimensional framework identifies civilizational, imperialist, globalist, and internationalist categories of exceptionalisms. While that classification differs from the one outlined here, the concern about the tension between universalism and particularism is an overlapping point.
} 
While this framework does not explain why certain role conceptions and identities arise at certain moments, it can still highlight how situations of crises can enable shifts along these dimensions. The rest of the article briefly outlines how these discourses have evolved since 2008.

\section{After the Crisis: Identity Discourses during the Obama and Trump Presidencies}

\section{The 2008-09 Crisis and Barack Obama's Election}

By the time of the 2008 presidential election, the military stalemates in Iraq and Afghanistan had already shaken the previously widely-shared belief in the U.S. capacity to unilaterally manage the international order. Barack Obama rose to the nomination of the Democratic Party by taking advantage of his consistent opposition to the Iraq war; ending the war became one of his major campaign promises. The financial meltdown happening in the final weeks of the campaign further strengthened Obama's position, while it contributed to a new sense of identity crisis. Amid the prospects of an economic downturn, the price of maintaining U.S. unipolarity seemed to become prohibitive; the internal support of the broad activist-universalist consensus also began to erode. ${ }^{4}$

Still, the discourse on exceptionalism did not die out. On the contrary, as the campaign moved closer to the finish, Republican politicians, such as vice-presidential candidate Sarah Palin, referred more frequently to the U.S. as exceptional (Cohen, 2008); while some right-wing commentators became fascinated with the question of whether Obama, the first African American major-party nominee, believed in the idea of exceptionalism (Emery, 2008). This development revealed yet another aspect of the U.S. identity crisis: as the country became increasingly diverse and multicultural, anxiety clearly had racial undertones, undermining the universalist U.S. self-view and reviving particularistic discourses. ${ }^{5}$ While Obama's election supposedly heralded a new, "postracial” era in U.S. politics, old divisions soon resurfaced. What was Obama's response as president?

\section{Barack Obama: "Imperfect Exceptionalism”}

\footnotetext{
${ }^{4}$ The debate on U.S. unipolarity played out both in elite discourses and in public opinion. In public surveys, the support for "staying out" of international affairs reached a record high of $41 \%$ by 2014 - although a majority still favored an "active part" (The Chicago Council of Global Affairs, 2014).

${ }^{5}$ Of course, this was not a completely new phenomenon. Debates on affirmative action, multiculturalism and immigration had been going on for decades.
} 
A few months after his inauguration, Obama was asked by a reporter about his opinion on U.S. exceptionalism. In a nuanced answer, Obama (2009) maintained his support for the old activist and universalist consensus as he reiterated his belief in the "continued extraordinary role [of the United States] in leading the world towards peace and prosperity." Nevertheless, he emphasized the imperfect nature of this role, and his statement that Americans believe in U.S. exceptionalism just as "the Brits believe in British exceptionalism, and the Greeks believe in Greek exceptionalism" became a source of ridicule and criticism by his Republican opponents. By the time of the 2012 election, Mitt Romney and his team partly built their case against Obama on the basis of "defending" "American exceptionalism" (Romney, 2011; Edwards, 2011). Once reelected, Obama (2013) again referred to exceptionalism as something imperfect and unfinished; situated in the context of "a never-ending journey" to approximate the ideas enshrined in the founding documents of the nation.

In his foreign policy, Obama similarly emphasized limits and restraint, while not discarding the possibility of forceful action. In response to developments such as the Arab Spring and the rise of ISIS, he continued to invoke U.S. identity in his justification of the use of force. For instance, when NATO intervened in Libya, Obama (2011) asserted that “to brush aside America's responsibilities as leader and ... responsibilities to our fellow human beings ... would have been a betrayal of who we are." Still, he emphasized the multinational nature of the endeavor, which was soon ridiculed as "leading from behind": in the end, he was caught in the middle between those who criticized him for not being "exceptionalist enough" and those who entirely opposed activism. Furthermore, his own position also evolved: in response to the use of chemical weapons in Syria, Obama chose not to follow the "Washington playbook" (despite his own previously-set red line). Therefore, by the end of his presidency, he moved closer toward a less activist position (cf. Goldberg, 2016), hence toward the exemplarist side of our framework, although he still used exceptionalist language.

\section{Donald Trump: "Great Again" and "America First"}

Donald Trump is not a fan of exceptionalism: even before announcing his run for the presidency, he claimed that he "never liked the term" (Corn, 2016), and he has rarely used it in his major speeches. ${ }^{6}$ Instead, Trump talks a lot about U.S. "greatness;" especially

\footnotetext{
${ }^{6}$ I thank Hilde Restad for drawing my attention to this 2015 quote by Trump.
} 
about a return to its past greatness, while his main foreign-policy slogan was "America First" - hardly the kind of leadership role that was advocated by recent presidents. ${ }^{7}$ In fact, the 2016 presidential election drew a sharp contrast between the two major candidates: while Hillary Clinton - as former first lady and secretary of state - personally symbolized the old universalist-activist consensus, Trump forcefully denounced that and also diverged from the Republican orthodoxies dominated by neoconservative views in the previous decades. While it is certainly difficult to discern any consistent position from his often-changing remarks, one thing seems to be constant: Trump rejects the universalist assumptions behind U.S. foreign policy, questioning the validity of such norms and values even in domestic politics. When he embraces autocrats or responds to criticism of his connections to Vladimir Putin with the remark that the U.S. is not "innocent" either, as they also "have a lot of killers" (Phillip, 2017), he - ironically - asserts just the idea of moral equivalency between countries that Obama was, mostly unfairly, accused of being a proponent of.

It is hard to characterize Trump's stance on activism vs. withdrawal: he could easily shift from full confrontation to a conciliatory tone or vice versa, as his statements about North Korea, Afghanistan or Syria demonstrated. But his approach to policies on immigration, refugees or trade has remained consistently particularistic: in fact, his nationalism - "[t]he future does not belong to the globalists," he declared at the U.N. (Trump, 2019) - revives an especially vile form of particularism. Although nostalgia about past greatness is a common political theme, in Trump's case, it also matters what kind of past he alludes to: some of his voters undoubtedly identify with his nostalgic references to once-existed and possibly eroding racial and gendered hierarchies in U.S. society. This backward-oriented domestic rhetoric is also reflected in the "America First" foreign policy that downplays international responsibility, and rather follows a transactional understanding of international politics through personal connections and bilateral relationships.

\section{Conclusion}

\footnotetext{
7 "America First" is also a historically loaded term, alluding to the name of the WWII-era isolationist America First Committee. For the history of the term, see also: Churchwell, 2018.
} 
Based on the available evidence, status or identity anxieties better explain Donald Trump's election victory than economic concerns (Schaffner et al., 2018; Sides et al., 2018). While this suggests an identity crisis at the subnational level, the 2016 campaign also drew attention to diverging interpretations of the U.S. self-view, which shows how a new sense of foreign-policy identity crisis can induce shifts in discourses of exceptionalism and greatness. The jury is still out to what extent Trump's undoubtedly unique way of saying things constitutes shifts in actual policies. Nevertheless, our assumption was that rhetoric itself could be a form of action, hence these discursive shifts may have long-lasting consequences as Trump definitely erodes those norms and values that used to be the basis of the United States' interactions with the world. This article presented a framework to categorize such U.S. identity discourses and found that the old universalist-activist consensus was partly questioned in the aftermath of the crises of 2008-09, while it was more fundamentally replaced following the election of Donald Trump. Further research is needed to decide how permanent these shifts are, and how a prospective new Democratic administration may respond to related challenges.

\section{References}

Brummer, Klaus and Thies, Cameron G. (2015). The Contested Selection of National Role Conceptions. Foreign Policy Analysis, 11: 273-293.

Campbell, David (1992). Writing Security. Manchester: Manchester University Press.

Ceaser, James W. (2012). The Origins and Character of American Exceptionalism. American Political Thought 1:1, 3-28.

The Chicago Council on Global Affairs (2014). 2014 Chicago Council Survey: Foreign Policy in the Age of Retrenchment. http://www.thechicagocouncil.org/survey/2014/chapter1.html [accessed Feb. 21, 2020].

Churchwell, Sarah (2018). Behold, America: A History of America First and the American Dream. London: Bloomsbury.

Cohen, Roger (2008). Palin's American Exception. The New York Times, Sept. 25, 2008, https://www.nytimes.com/2008/09/25/opinion/25Cohen.html [accessed Feb. 21, 2020].

Corn, David (2016). Donald Trump Says He Doesn't Believe in “American Exceptionalism." Mother Jones, June 7, 2016, 
https://www.motherjones.com/politics/2016/06/donald-trump-american-

exceptionalism/ [accessed Feb. 21, 2020].

Deudney, Daniel and Meiser, Jeffrey (2009). American Exceptionalism. In: Mick Cox and Douglas Stokes, eds., U.S. Foreign Policy. New York: Oxford University Press, 21-39.

Edwards, Jason A. (2011). Contemporary conservative constructions of American exceptionalism. Journal of Contemporary Rhetoric, 1:2, 40-54.

Emery, Noemie (2008). Evil Under the Sun. The Weekly Standard, Nov. 3, 2008, https://www.washingtonexaminer.com/weekly-standard/evil-under-the-sun [accessed Feb. 21, 2020].

Goldberg, Jeffrey (2016). The Obama Doctrine. The Atlantic, April 2016, https://www.theatlantic.com/magazine/archive/2016/04/the-obamadoctrine/471525/ [accessed Feb. 21, 2020].

Guzzini, Stefano (2012). The framework of analysis: geopolitics meets foreign policy crises. In: Guzzini, ed., The Return of Geopolitics in Europe? Social Mechanisms and Foreign Policy Identity Crises. Cambridge: Cambridge University Press, 4574.

Hoffmann, Stanley (1968). Gulliver's Troubles, or the Setting of American Foreign Policy. New York: McGraw-Hill.

Hoffmann, Stanley (1978). Primacy or World Order: American Foreign Policy since the Cold War. New York: McGraw-Hill.

Holsti, Kalevi J. (1970). National Role Conceptions in the Study of Foreign Policy. International Studies Quarterly, 14:3, 233-309.

Hughes, David (2015). Unmaking an exception: A critical genealogy of US exceptionalism. Review of International Studies, 41:3, 527-551.

Hunt, Michael H. (1987). Ideology and U.S. Foreign Policy. New Haven: Yale University Press.

Klingberg, Frank L. (1952). The Historical Alternation of Moods in American Foreign Policy. World Politics, 4:2, 239-273.

Koh, Harold Hongju (2003). On American exceptionalism. Stanford Law Review, 55:5, 1479-1527.

Krauthammer, Charles (1990/91). The Unipolar Moment. Foreign Affairs, 70:1 (America and the World issue, 1990/91), 23-33. 
McCrisken, Trevor (2003). American Exceptionalism and the Legacy of Vietnam: US Foreign Policy since 1974. New York: Palgrave Macmillan.

McDougall, Walter A. (1997). Promised Land, Crusader State: The American Encounter with the World since 1776. Boston: Houghton Mifflin.

Nymalm, Nicola and Plagemann, Johannes (2019). Comparative Exceptionalism: Universality and Particularity in Foreign Policy Discourses. International Studies Review, 21:1, 12-37.

Obama, Barack (2009). News Conference by President Obama, Strasbourg. April 4, 2009. https://obamawhitehouse.archives.gov/the-press-office/news-conferencepresident-obama-4042009 [accessed Feb. 21, 2020].

Obama, Barack (2011). Remarks by the President in Address to the Nation on Libya. March 28, 2011, https://obamawhitehouse.archives.gov/the-pressoffice/2011/03/28/remarks-president-address-nation-libya [accessed Feb. 21, 2020].

Obama, Barack (2013). Second Inaugural Address. January 21, 2013, https://obamawhitehouse.archives.gov/the-press-office/2013/01/21/inauguraladdress-president-barack-obama [accessed Feb. 21, 2020].

Onuf, Peter S. (2012). American Exceptionalism and National Identity. American Political Thought, 1:1, 77-100.

Phillip, Abby (2017). O'Reilly told Trump that Putin is a killer. Trump's reply: 'You think our country is so innocent?' The Washington Post, Feb. 4, 2017, https://www.washingtonpost.com/news/post-politics/wp/2017/02/04/oreilly-toldtrump-that-putin-is-a-killer-trumps-reply-you-think-our-countrys-so-innocent/ [accessed Feb. 21, 2020].

Restad, Hilde Eliassen (2015). American Exceptionalism: An Idea that Made a Nation and Remade the World. London: Routledge.

Rodgers, Daniel T. (2004). American Exceptionalism Revisited. Raritan, 24:2, 21-47.

Romney, Mitt (2011). Speech on Foreign Policy at the Citadel. The Wall Street Journal, October 7, 2011, https://blogs.wsj.com/washwire/2011/10/07/text-of-mittromneys-speech-on-foreign-policy-at-the-citadel/ [accessed Feb. 21, 2020].

Schaffner, Brian F., MacWilliams, Matthew and Nteta, Tatisha (2018). Understanding White Polarization in the 2016 Vote for President: The Sobering Role of Racism and Sexism. Political Science Quarterly, 133:1, 9-34. 
Sides, John, Tesler, Michael and Vavreck, Lynn (2018). Identity Crisis: The 2016 Presidential Campaign and the Battle for the Meaning of America. Princeton and Oxford: Princeton University Press.

Trump, Donald J. (2019). Remarks by President Trump to the 74th Session of the United Nations General Assembly. New York, September 24, 2019, https://www.whitehouse.gov/briefings-statements/remarks-president-trump74th-session-united-nations-general-assembly/ [accessed Feb. 21, 2020].

Tucker, Robert W. and Hendrickson, David C. (1992). The Imperial Temptation: The New World Order and America's Purpose. New York: Council of Foreign Relations. 